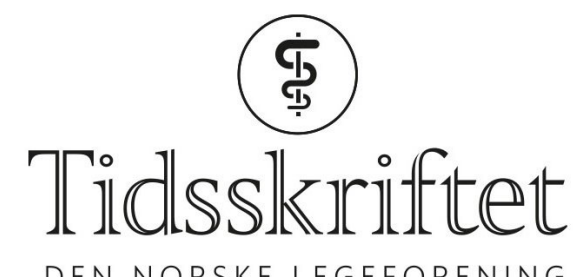

DEN NORSKE LEGEFORENING

\title{
Blir man syk av stress?
}

ANMELDELSER

GUNNAR TELLNES

Professor, Avdeling for samfunnsmedisin og global helse, Institutt for helse og samfunn, Universitetet i Oslo

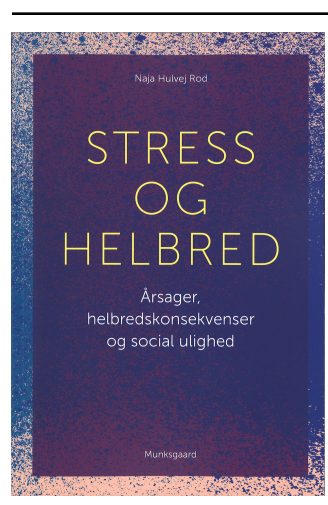

Naja Hulvej Rod

Stress og helbred

Årsager, helbredskonsekvenser og social ulighed. 151 s, ill. København: Munksgaard, 2017.

Pris DKK 249

ISBN 978-87-628-1586-5

På en lettfattelig måte presenterer forfatteren dagens forskningsbaserte kunnskap om stressets fysiologi, hvordan stress påvirker immunsystemet og betydningen for utvikling av sykdom. Dette gjelder blant annet hjerte- og karsykdommer, diabetes, brystkreft, nevrogenerative sykdommer og allergiske sykdommer. Dessuten omtales i egne kapitler «sosial ulikhet i stress» og sammenhengen mellom «stress og dødelighet».

Boken bygger på forfatterens egen forskning og gjennomgang av annen relevant litteratur som er gjort i forbindelse med hennes doktorgradsarbeid «Stress and Health» ved Universitetet i København i 2014. Boken har allmenn interesse, men er kanskje mest spennende for dem som forsker på samme tema, og for leger og annet helsepersonell som arbeider med å forebygge og behandle de sykdomsgruppene som omtales.

Forfatteren påpeker at stress ofte er en naturlig fysiologisk respons som følge av overbelastning fra omgivelsene, og dermed hensiktsmessig for liv og helse. Kanskje dette er grunnen til at forskningen ikke alltid er entydig i spørsmålet om stress fører til sykdom eller ikke? Mer kompleks blir sammenhengen mellom stress og helse når vi leser om årsaker til stress. Opplevde belastninger i livet kan akkumuleres over tid og på lengre sikt føre til sykdom. Dette gjelder ikke bare psykososiale faktorer, men også fysiske belastninger 
som støy, kulde og stress som vi opplever når vi over tid sliter med en kronisk sykdom.

Arbeidsrelatert stress er i flere undersøkelser dokumentert som uheldig for helsen. Et eksempel på dette er når en arbeidstaker opplever å ha gjort en stor arbeidsinnsats, men ikke blir anerkjent for dette. En ubalanse mellom anstrengelse og belønning kan på lengre sikt føre til manglende selvfølelse og selvtillit. Forfatteren beskriver også hva som kan forebygge stress på arbeidsplassen. Det fremheves forskning som viser en sammenheng mellom sosial kapital som en organisatorisk ressurs, og faktorer som arbeidsmiljø, trivsel og effektivitet.

Boken er egnet for helsepersonell og forskere som er interessert i sammenhengen mellom stress og de store folkesykdommene. Etter å ha lest boken savner jeg mer kunnskap om helsekonsekvensene av stress relatert til «multitasking». Hvordan påvirker for eksempel «tidsklemma», i arbeid, skole, hjem og fritid, vår fysiske og mentale funksjon, arbeidsevne og trivsel? Kanskje kan slik forskning hjelpe oss til å forstå årsakene til høyt sykefravær og $ø$ kende andel uføre blant dagens unge?

Publisert: 28. november 2017. Tidsskr Nor Legeforen. DOI: 10.4045/tidsskr.17.0769

(C) Tidsskrift for Den norske legeforening 2020. Lastet ned fra tidsskriftet.no 